\title{
Examining Student Satisfaction Of Online Statistics Courses
}

\author{
Ahmed Al-Asfour, Oglala Lakota College, USA
}

\begin{abstract}
This survey research of 55 participants was completed at a private university to determine students' satisfaction of statistic online courses. The study explored the students' satisfaction of course components: online statistics, online instruction, communication, assessment, and overall student satisfaction. The findings showed a positive satisfaction with overall means between 3.66 and 4.00 in a 5 point Likert-scale with a 5 meaning strong agreement with satisfaction of the course. The highest area of satisfaction was the category of assessment $(M=4.00)$ and the lowest area was the category of student overall satisfaction $(M=3.66)$. In addition, the study examined age, gender, teaching experience, and overall satisfaction of the course with the overall average of satisfaction.
\end{abstract}

Keywords: e-learning Statistics; Online Courses

\section{INTRODUCTION}

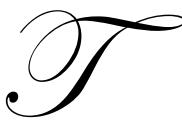

his research study examines student satisfaction of online statistic courses at a private university. Furthermore, this paper explores student satisfaction based on five aspects of online education, including teaching statistics online (Kreiner, 2006; Mills \& XU, 2006; Rynearson, \& Kerr, 2005), online instruction (Kelly \& Walker, 2007; Swan 2003), communication (Betts, 2009; Cakmak, Karatas, \& Ocak, 2009), assessment (Ross \& Ross, 2005; Rovai, 2000), and student overall satisfaction. Research related to online student satisfaction has been conducted by several researchers (Drennan, Kennedy, \& Pisarski, 2005; Madernach, 2005; Sampson, Leonard, Ballenger, \& Coleman, 2010; Young \& Norgard, 2006). Although research on student satisfaction related to online and hybrid courses have been published in many peer review journals, little has been published on student satisfaction relating to online statistic instruction courses.

Online education is a method of instruction that allows students and instructors to interact with each other using the Internet as a method of communication. The use of the Internet was slow in the 1990s. However, in a relatively short period of time, it has been expanding exponentially. Due to this, public and private universities alike have been offering many classes on the Internet. Distance education is also used in training and other professional development programs (Quesada-Pineda, Conn, \& Sanchez, 2011; Sobrero \& Craycraft, 2008).

Adopting online education comes with many concerns. One concern is that many students attending universities are increasingly nontraditional students who must balance work, family and college courses. Another concern as reported by Rynearson and Kerr (2005) is that some students entering graduate programs after receiving their undergraduate degree have weak quantitative skills.

In addition, distance education requires different skills and competencies from traditional classroom learning. For example, students in face-to-face environment do not need to be technology savvy, whereas e-learners must master some technological skills to ensure their success in this method of learning. Online learners might be asked to use some software to enhance their learning such as SPSS. In this case, e-learners will not only struggle with statistic courses being taught online, but also to learn how to use some of the software on their own. Hence, understanding student satisfaction with their courses is important in order for the instructor and the university to become able to resolve any dissatisfaction students might encounter with their online courses. 


\section{ENVIRONMENTAL CONTEXT}

The impetus for developing an online version of a particular statistics course was derived from two distinct sources. Because the university is situated in a remote area of the state and has thousands of students online, it is important to offer courses in an online environment in order to accommodate students. The other reason is that many of the graduate students are nontraditional students. This means that some of these students have work and family responsibilities. The online environment offers these students the flexibility to take this course at any time that fits their schedule. In addition, online courses must be structured to balance the goal of learner centeredness and leaner responsibility. Kearsly (2000) reported a theme and that is "student-centeredness" (p.4). Thus, online courses offer the opportunity for students to have their online courses work around their schedule not vice versa.

The goal of this study was to examine student satisfaction of online statistics courses. As stated earlier, there have been several studies, which have examined student satisfaction of online courses. However, few have been done on statistics classes delivered online. Therefore, there is a need to investigate student satisfaction in an online educational setting. The findings of this study may contribute to the literature of online education in terms of student satisfaction on statistics online courses. The results should also enable colleges and universities offering statistics online courses to evaluate their online curriculums.

Answers to the following research questions were sought in this study.

1- $\quad$ Are students who are taking graduate statistic online courses satisfied with their online course experiences on specific components of online statistics, online instruction, communication, assessment, and overall student satisfaction?

2- What is the relationship between students' demographics in terms of age, education experience and their level of satisfaction, and gender?

\section{METHODS}

\section{Participants}

A sample of students who were taking statistics online courses at a private university participated in this study through a survey. Fifty five students completed the survey out of a total of 60 students asked to participate in this study.

\section{Instrument}

A survey was developed addressing the components of the quality of the course. The survey consisted of two parts. The first section had demographic information of students who registered in the class. The second part of the survey included teaching statistics online, online instruction, communication, assessment, and overall students' satisfaction. Prior to sending the survey to everyone in the class, the survey was field tested with a few students in the class. Recommendations were made and accordingly adopted into the survey. The participants in this study chose agree or disagree on a likert-scale of one to five with five being "strongly agree" and one being "strongly disagree". The survey was sent to the students through SurveyMonkey. The completion of the survey was anonymous to the instructor and to other students. It was a voluntary survey to all students in the class.

\section{Data Analysis}

Descriptive statistics using SPSS was utilized to analyze students' overall satisfaction of the following categories: taking statistics online, online instruction, communication, assessment, and overall student satisfaction. In order to analyze each category, frequencies and means were established on the statements with an overall mean for each statement on the survey. 


\section{FINDINGS}

The first research question explored the students' satisfaction with five specific components: online statistics, online instruction, communication, assessment, and overall student satisfaction. Students completed an online survey of 10 statements, 2 statements for each component. Using a Likert Scale ranging from 1 (Strongly disagree) to 5 (Strongly agree) participants were asked to gauge their satisfaction with the online course. Statements were indexed according to the statements for each component.

Table 1 shows summary of the means and standard deviations for the components examined in this study

\begin{tabular}{lllrc}
\hline & Components & N & Mean & Std Deviation \\
\hline 1. & Taking Statistics online & 55 & 3.80 & 0.941 \\
2. & Online Instruction & 55 & 3.93 & 1.099 \\
3. & Communication & 55 & 3.86 & 1.187 \\
4. & Assessment & 55 & 4.00 & 1.069 \\
5. & Student Overall Satisfaction & 55 & 3.66 & 1.069 \\
\hline
\end{tabular}

The participants in this study expressed the strongest agreement of satisfaction with the components of assessment $(\mathrm{M}=400)$. The other components that followed were, online instruction $(\mathrm{M}=3.93)$, communication $(\mathrm{M}=$ 3.86), taking statistics online $(\mathrm{M}=3.80)$, and student overall satisfaction $(\mathrm{M}=3.66)$.

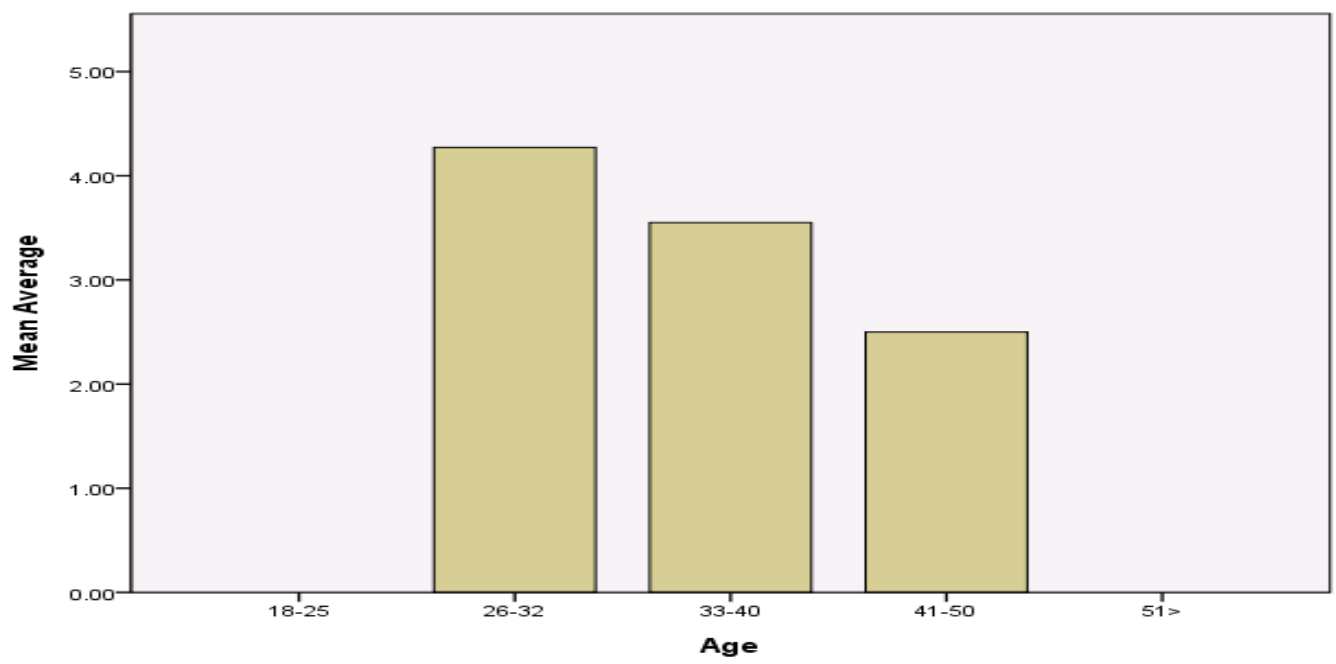

Figure 1. Average satisfaction with statistics online courses by age

Based on age demographic in Figure 1, the participants from the age of 26 to 32 showed more satisfaction than those who were from 33-40 and 41-50. In addition, this shows that the younger the participants, the more satisfied with using technology in e-learning. 


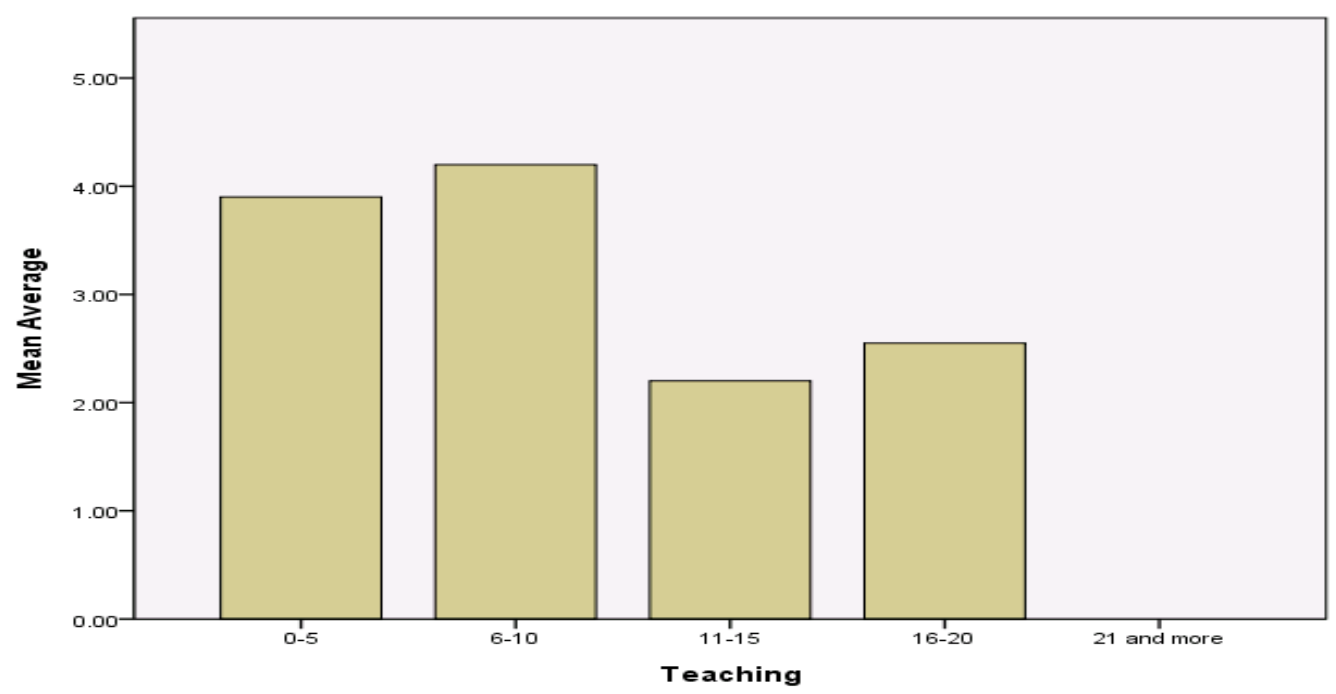

Figure 2. Average satisfaction with statistics online courses by number teaching experience

In Figure 2, it shows the number of years that the participants have in teaching. All of the participants have had a number of years teaching face-to-face and online. In addition, it illustrates in Figure 2 that the participants who had teaching experience of 6 to 10 years were a little more satisfied with taking the statistics course online followed by 0 to 5 years, 16-20, and 11-15. No students under the age of 21 participated in this study.

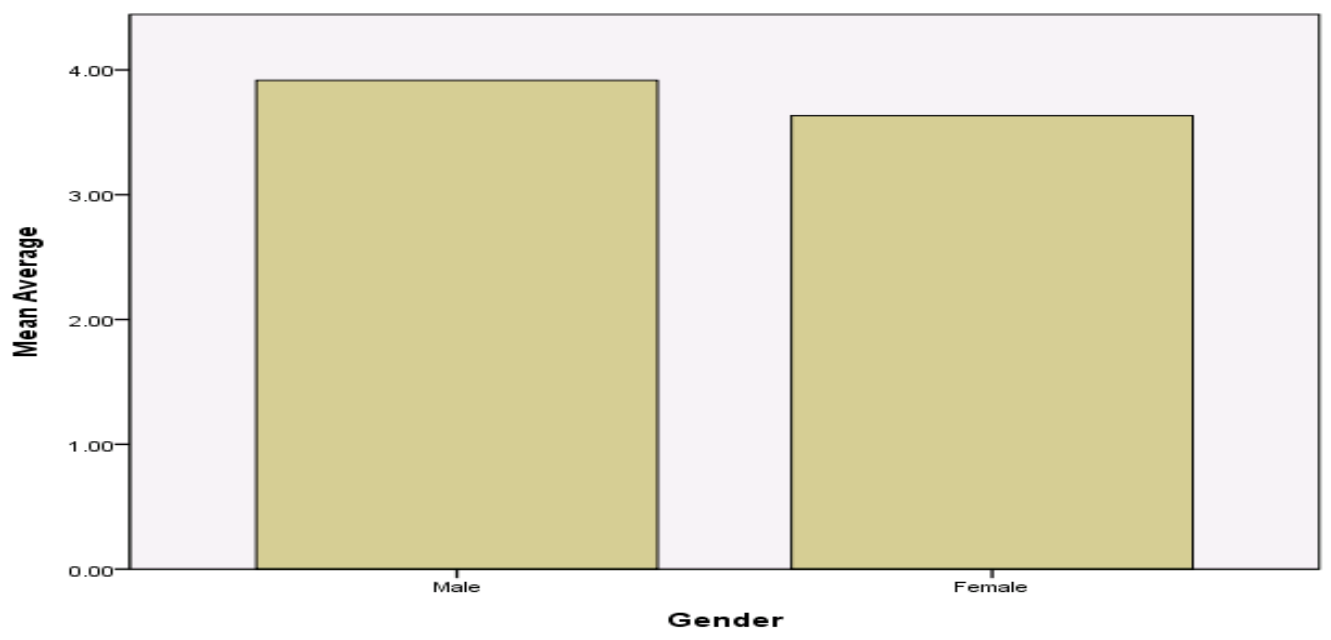

Figure 3. Average satisfaction with statistics online courses by gender

In Figure 3, the result shows that male participants were a little more satisfied with taking statistics course. Since the mean is very close, the researcher cannot conclude that there is a relationship between genders and statistician of online courses.

The results of the overall satisfaction of students who were taking the course (M=3.66), ( $\mathrm{SD}=1.069)$. This means that students were indeed satisfied with taking this course in an online environment. 


\section{CONCLUSIONS AND IMPLICATIONS}

Data gleaned from this study showed satisfaction with the components examined. The majority of participants agreed that they were satisfied with online learning. The mean scores for the five components ranged from 3.66 to 400 . Student overall satisfaction was slightly lower $(M=3.66)$. This can be attributed to other factors and/or components that were not measured in this study.

While this research examined student satisfaction of online statistic courses at one university, further research is suggested to be conducted in different statistic courses at different universities. In addition, more research is needed to compare statistic courses being taught using face-to-face method with online settings. Because only 55 students participated in the study, a larger sample is suggested in order to have a larger picture of the overall satisfaction of statistic courses being taught online. Other components should also be examined in other studies.

The potential of e-learning is on the rise and more universities are offering courses in statistics in an online environment. Because of this, researchers need to investigate new methods and ideas of making students more satisfied with their courses. The future of e-learning dictates a willingness by instructors and institutions to increase the level of students' satisfaction for the sake of increasing students' retention and outcomes.

\section{AUTHOR INFORMATION}

Ahmed Al-Asfour is an Associate Professor at Oglala Lakota College (OLC). He has been in the Business Department of OLC (Kyle, SD) for the past four years and his research interests are in the areas of: leadership, retention, motivation, educational methods, and training \& development skills for students and employees. E-mail: aalasfour@olc.edu

\section{REFERENCES}

1. Betts, K. (2009). Lost in translation: Importance of effective communication in online education. Online Journal of Distance Learning Administration, 12 (2). Retrieved from http://www.westga.edu/ distance/ojdla/summer122/betts122.html.

2. Cakmak, E., K, Karatas, S, \& Ocak, A. (2009). An analysis of factors affecting community college students' expectations on e-learning. The Quarterly Review of Distance Education, 10(4), 351-361.

3. Drennan, J. A., Kennedy, J., \& Pisarski, A. (2005). Factors affecting student attitudes toward flexible online learning in management education. Journal of Educational Research, 98(6), 331-338.

4. Kearsley, G. (2000). Online education: Learning and teaching in cyberspace. Belmont, CA: Wadsworth

5. Kelly, E., \& Walker, C.E. (2007). Online instruction: Student satisfaction, kudos, and pet peeves. Quarterly Review of Distance Education, 8(4), 309-319.

6. Kreiner, D.S. (2006). A mastery-based approach to teaching statistics online. International Journal of Instructional Media, 33(1), 73-80

7. Madernach, B.J. (2005). A faculty evaluation model for online instructor: Mentoring and evaluation in the online classroom. Online Journal of Distance Learning Administration, 8 (3), 1-10.

8. Mills, J.D., \& Xu, Y. (2006). Statistics at a distance: Technological tools, learning, and design features for today's modern course. Journal of Educational Technology Systems, 34 (4), doi:10.2190/DHKE-84EC76GA-XBAT.

9. Quesada-Pineda, H. J., Conn, S. S., Sacnchez, L, S. (2011). A survey of educational needs and online training perceptions in the wood products industry. Journal of Extension [On-line], 49(1). Retrieved from http://www.joe.org/joe/2011february/rb6.php.

10. Ross, J.A., \& Ross, M. (2005). Student assessment in online courses: Research and practice. Canadian Journal of University Education, 31 (2), 37-57.

11. Rovai, A.P. (2000). Online and traditional assessments: What is the difference? Internet and Higher Education, 3(3), 141-151.

12. Rynearson, K., \& Kerr, M.S. (2005). Teaching statistics online in a blended learning environment. Journal of Computer in Higher Education, 17 (1), 71-94. 
13. Sampson, P.M., Leonard, J., Ballenger, J.W., \& Coleman, J.C. (2010). Student satisfaction of online courses for educational leadership. Online Journal of Distance Learning Administration, XIII (III), 1-12.

14. Sobrero, P.M., \& Craycraft, C.G. (2008). Virtual communities of practice: A $21^{\text {st }}$ century method for learning programming, and developing professionally. Journal of Extension [On-line], 46(5). Retrieved from at: http://www.joe.org/joe/2008october/a1.php

15. Swan, K. (2003). Learning effectiveness online: What the research tells us. Quality Online Education, 1345 .

16. Young, A., \& Norgard, C. (2006). Assessing the quality of online courses form the students' perspective. Internet and Higher Education, 9(2), 107-115. 